\title{
Front Matter: Volume 8698
}

, "Front Matter: Volume 8698," Proc. SPIE 8698, Optical Fibers and Their Applications 2012, 869801 (23 January 2013); doi: 10.1117/12.2020581

SPIE. Event: Optical Fibers and Their Applications 2012, 2012, Krasnobrod, Poland 


\title{
PROCEEDINGS OF SPIE
}

\section{Optical Fibers and Their Applications 2012}

\author{
Ryszard S. Romaniuk \\ Waldemar Wójcik \\ Editors
}

\section{9-12 October 2012}

Lublin and Nałęczów, Poland

\section{Organized by}

Laboratory of Optical Fiber Technology, Faculty of Chemistry, Maria Curie-Skłodowska University, Lublin (Poland)

Institute of Electronics and Information Technology, Lublin University of Technology (Poland)

Sponsored by

Committee of Electronics and Telecommunication, Polish Academy of Sciences

Polish Committee of Optoelectronics of SEP - Association of Polish Electrical Engineers

Photonics Society of Poland

Published by

SPIE 
The papers included in this volume were part of the technical conference cited on the cover and title page. Papers were selected and subject to review by the editors and conference program committee. Some conference presentations may not be available for publication. The papers published in these proceedings reflect the work and thoughts of the authors and are published herein as submitted. The publisher is not responsible for the validity of the information or for any outcomes resulting from reliance thereon.

Please use the following format to cite material from this book:

Author(s), "Title of Paper," in Optical Fibers and Their Applications 2012, edited by Ryszard

S. Romaniuk, Waldemar Wójcik, Proceedings of SPIE Vol. 8698 (SPIE, Bellingham, WA, 2013) Article CID Number.

ISSN: 0277-786X

ISBN: 9780819494856

Published by

SPIE

P.O. Box 10, Bellingham, Washington 98227-0010 USA

Telephone +1 3606763290 (Pacific Time) · Fax +1 3606471445

SPIE.org

Copyright @ 2013, Society of Photo-Optical Instrumentation Engineers.

Copying of material in this book for internal or personal use, or for the internal or personal use of specific clients, beyond the fair use provisions granted by the U.S. Copyright Law is authorized by SPIE subject to payment of copying fees. The Transactional Reporting Service base fee for this volume is $\$ 18.00$ per article (or portion thereof), which should be paid directly to the Copyright Clearance Center (CCC), 222 Rosewood Drive, Danvers, MA 01923. Payment may also be made electronically through CCC Online at copyright.com. Other copying for republication, resale, advertising or promotion, or any form of systematic or multiple reproduction of any material in this book is prohibited except with permission in writing from the publisher. The CCC fee code is 0277-786X/13/\$18.00.

Printed in the United States of America.

Publication of record for individual papers is online in the SPIE Digital Library.

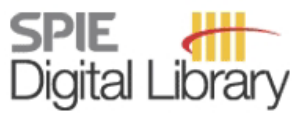

SPIEDigitalLibrary.org

Paper Numbering: Proceedings of SPIE follow an e-First publication model, with papers published first online and then in print and on CD-ROM. Papers are published as they are submitted and meet publication criteria. A unique, consistent, permanent citation identifier (CID) number is assigned to each article at the time of the first publication. Utilization of CIDs allows articles to be fully citable as soon as they are published online, and connects the same identifier to all online, print, and electronic versions of the publication. SPIE uses a six-digit CID article numbering system in which:

- The first four digits correspond to the SPIE volume number.

- The last two digits indicate publication order within the volume using a Base 36 numbering

system employing both numerals and letters. These two-number sets start with 00, 01, 02, 03, 04, $05,06,07,08,09,0 A, 0 B \ldots$. 0Z, followed by 10-1Z, 20-2Z, etc.

The CID Number appears on each page of the manuscript. The complete citation is used on the first page, and an abbreviated version on subsequent pages. Numbers in the index correspond to the last two digits of the six-digit CID Number. 


\section{Contents}

vii Conference Committee

xi Introduction

\section{SESSION 1 OPTICAL FIBERS AND PLANAR OPTICAL WAVEGUIDES}

869802 Upconversion luminescence in tellurite optical fiber codoped with $\mathrm{Yb}^{3+} / \mathrm{Ho}^{3+}$ ions (Invited Paper) [8698-2]

M. Kochanowicz, W. Mazerski, J. Zmojda, D. Dorosz, Politechnika Bialostocka (Poland)

869803 UDWDM system with original tunable coherent receiver [8698-4]

J. Lamperski, Poznan Univ. of Technology (Poland)

869804 Fresnel lens fabrication for MidIR optics and fiber optic technique by using hot embossing process [8698-6]

I. Kujawa, Institute of Electronic Materials Technology (Poland); R. Kasztelanic, P. Waluk, Univ. of Warsaw (Poland); R. Stępień, K. Haraśny, D. Pysz, M. Klimczak, Institute of Electronic Materials Technology (Poland); R. Buczyński, Institute of Electronic Materials Technology (Poland) and Univ. of Warsaw (Poland)

869805 Optical fibers and their applications 2012 [8698-7]

R. S. Romaniuk, Politechnika Warszawska (Poland); W. Wójcik, Politechnika Lubelska (Poland)

869806 Chromatic dispersion estimation from input and output intensity waveforms in a fiber optic link with non-zero chirp Mach-Zehnder modulator [8698-9]

Z. T. Lach, Politechnika Lubelska (Poland)

869807 Composite optical waveguide structures: technology and features [8698-33]

P. Karasiński, C. Tyszkiewicz, R. Rogoziński, Silesian Univ. of Technology (Poland)

\section{SESSION 2 BIOPHOTONICS I}

869808 Laser photoplethysmography in integrated evaluation of collateral circulation of lower extremities (Invited Paper) [8698-11]

S. V. Pavlov, Vinnytsia National Technical Univ. (Ukraine); S. V. Sander, Vinnytsia National Medical Univ. (Ukraine); T. I. Kozlovska, A. S. Kaminsky, Vinnytsia National Technical Univ. (Ukraine); W. Wojcik, Politechnika Lubelska (Poland); M. Sh. Junisbekov, Taraz State Univ. (Kazakhstan) 
869809 Laser polarization fluorescence of the networks of optically anisotropic biological crystals [8698-16]

Y. A. Ushenko, A. V. Dubolazov, A. P. Angelsky, M. I. Sidor, Yuriy Fedkovych Chernivtsi National Univ. (Ukraine); G. B. Bodnar, G. Koval, Bukovinian State Medical Univ. (Ukraine): N. I. Zabolotna, Vinnytsia National Technical Univ. (Ukraine); A. Smolarz, Politechnika Lubelska (Poland); M. Sh. Junisbekov, Taraz State Univ. (Kazakhstan)

8698 OA Methods of processing biomedical image of retinal macular region of the eye [8698-17] S. V. Pavlov, Vinnytsia National Technical Univ. (Ukraine); V. B. Vassilenko, Univ. Nova de Lisboa (Portugal); D. V. Vovkotrub, A. A. Poplavskaya, Vinnytsia National Technical Univ. (Ukraine); O. Hotra, Politechnika Lubelska (Poland)

8698 OB Spectropolarimetry and fluorescence in biotissue cancer diagnostics [8698-18] S. Yermolenko, P. Ivashko, Yuriy Fedkovych Chernivtsi National Univ. (Ukraine); W. Surtel, Politechnika Lubelska (Poland)

8698 OC Diagnostics of pathologically changed birefringent networks by means of phase Mueller matrix tomography [8698-19]

N. I. Zabolotna, Vinnytsia National Technical Univ. (Ukraine); W. Wojcik, Politechnika Lubelska (Poland); S. V. Pavlov, Vinnytsia National Technical Univ. (Ukraine); O. G. Ushenko, Yuriy Fedkovych Chernivtsi National Univ. (Ukraine); B. Suleimenov, Kazakh National Technical Univ. (Kazakhstan)

8698 OD Differential phase analysis of laser images of a polycrystalline component of blood plasma in diagnostics of pathological changes in mammary gland [8698-23] O. P. Mintser, National Medical Academy of Post-Graduate Education (Ukraine); N. I. Zabolotna, Vinnytsia National Technical Univ. (Ukraine); B. P. Oliinychenko, National Taras Shevchenko Univ. of Kyiv (Ukraine); P. Komada, Politechnika Lubelska (Poland)

\section{SESSION 3 BIOPHOTONICS II}

8698 OE Diagnostics of pathologically changed birefringent networks by means of phase Mueller matrix tomography (Invited Paper) [8698-24]

N. I. Zabolotna, Vinnytsia National Technical Univ. (Ukraine); W. Wojcik, Politechnika Lubelska (Poland); S. V. Pavlov, Vinnytsia National Technical Univ. (Ukraine); O. G. Ushenko, Yuriy Fedkovych Chernivtsi National Univ. (Ukraine); B. Suleimenov, Kazakh National Technical Univ. (Kazakhstan)

8698 OF Research of the spectral diffuse reflectance of melanoma in vivo [8698-25]

V. G. Petruk, Vinnytsia National Technical Univ. (Ukraine); D. B. Bolyuh, Vinnytsia National Medical Univ. (Ukraine); S. M. Kvaternyuk, Vinnytsia National Technical Univ. (Ukraine); O. E. Kvaternyuk, Vinnytsia Humanitarian Pedagogical College (Ukraine); Y. M. Denysiuk, Vinnytsia National Technical Univ. (Ukraine); A. Kotyra, Politechnika Lubelska (Poland)

8698 OG Applications of discriminant analysis methods in medical diagnostics [8698-27] T. B. Martyniuk, Vinnytsia National Technical Univ. (Ukraine); L. M. Kupershtein, Politechnika Lubelska (Poland); A. V. Medvid, A. V. Kozhemiako, Vinnytsia National Technical Univ. (Ukraine); W. Wojcik, Politechnika Lubelska (Poland); O. Yuchshenko, Kazakh National Technical Univ. (Kazakhstan) 
$8698 \mathrm{OH}$ The spectral polarimetric control of phytoplankton in photobioreactor of the wastewater treatment [8698-29]

V. G. Petruk, S. M. Kvaternyuk, Y. M. Denysiuk, Vinnytsia National Technical Univ. (Ukraine);

K. Gromaszek, Politechnika Lubelska (Poland)

$8698 \mathrm{Ol}$ Automation of measurement processing of substance concentration in water by photometric methods in monitoring and control system of a state [8698-31]

V. B. Mokin, M. P. Botsula, A. R. Yascholt, Vinnytsia National Technical Univ. (Ukraine); W. Wojcik, Politechnika Lubelska (Poland); A. Burlibay, Kazakh National Technical Univ. (Kazakhstan)

\section{SESSION 4 OPTOELECTRONIC DEVICES AND SYSTEMS}

8698 0J Development of noncoherent optical-electronic systems in modern photo medical technology (Invited Paper) [8698-10]

Z. Yr. Hotra, A. T. Kozhukhar, A. M. Zazuljak, M. S. Ivakh, Lviv Polytechnic National Univ. (Ukraine)

8698 OK The method of cross-section for controling laser beam spot image shape [8698-12] L. I. Tymchenko, SETUT Kiev (Ukraine); Yu. F. Kutaev, KIA Systems Moskow (Russian Federation); M. Petrovskyi, N. I. Kokryatskaya, A. E. Denysova, SETUT Kiev (Ukraine); D. Porubov, Kazakh National Technical Univ. (Kazakhstan); W. Wojcik, Politechnika Lubelska (Poland)

$8698 \mathrm{OL}$ Microfacet distribution function for physically based bidirectional reflectance distribution functions [8698-13]

O. N. Romanyuk, S. V. Pavlov, R. Yu. Dovhaliuk, N. P. Babyuk, M. D. Obidnyk, Vinnytsia National Technical Univ. (Ukraine); P. Kisala, Politechnika Lubelska (Poland); B. Suleimenov, Kazakh National Technical Univ. (Kazakhstan)

8698 OM Optoelectronic spiking neural network [8698-14]

V. P. Kozemiako, O. K. Kolesnytskyj, T. S. Lischenko, Vinnytsia National Technical Univ. (Ukraine); W. Wojcik, Politechnika Lubelska (Poland); A. Sulemenov, Kazakh National Technical Univ. (Kazakhstan)

8698 ON Static and dynamic characteristics of the self-calibrating multibit ADC analog components [8698-30]

O. D. Azarov, O. D. Dudnyk, Vinnytsia National Technical Univ. (Ukraine); M. Duk,

Politechnika Lubelska (Poland); D. Porubov, Kazakh National Technical Univ. (Kazakhstan)

\section{SESSION 5 PHOTONICS APPLICATIONS}

869800 TRIDAQ systems in HEP experiments at LHC accelerator (Invited Paper) [8698-21]

A. Zagozdzińska, R. S. Romaniuk, K. T. Poźniak, Politechnika Warszawska (Poland);

P. Zalewski, National Ctr. for Nuclear Research, Świerk (Poland)

8698 OP Laser technology 2012 [8698-8]

R. S. Romaniuk, Politechnika Warszawska (Poland); J. Gajda, Szczecin Univ. of Technology (Poland) 
$86980 Q \quad$ Review of EuCARD project on accelerator infrastructure in Europe [8698-22]

R. S. Romaniuk, Politechnika Warszawska (Poland)

8698 OR Modified cooperative immune algorithm for solving classification problems [8698-20]

W. Wójcik, Politechnika Lubelska (Poland); V. Lyłvynenko, Kherson National Technical Univ. (Ukraine); S. Smailova, D. Serikbayev East Kazakhstan State Technical Univ. (Kazakhstan)

8698 OS Optical fibers and photonics applications: topical tracks at Wilga conferences [8698-32] R. S. Romaniuk, Politechnika Warszawska (Poland)

8698 OT Methods and resources for imaging polarimetry [8698-26]

J. R. Rovira, Univ. Estatal Península de Santa Elena (Ecuador); S. V. Pavlov, Vinnytsia National Technical Univ. (Ukraine); V. B. Vassilenko, Univ. Nova de Lisboa (Portugal): W. Wójcik, Politechnika Lubelska (Poland); L. Sugurova, Kazakh National Technical Univ. (Kazakhstan)

8698 OU Mathematical model of radiation interaction with gas [8698-28]

O. V. Osadchuk, D. P. Dudnyk,; R. V. Krynochkin, Vinnytsia National Technical Univ. (Ukraine); W. Wojcik, Politechnika Lubelska (Poland); A. Iskakova, Kazakh National Technical Univ. (Kazakhstan)

Author Index 


\section{Conference Committee}

Honorary Committee

Wiesław L. Woliński, Chair, Full Member of Polish Academy of Sciences, Warsaw University of Technology (Poland)

Leszek Stoch, AGH University of Science and Technology, Kraków (Poland)

Aleksander Opilski, deceased, Silesian University of Technology, Gliwice (Poland)

Scientific Committee

Waldemar Wójcik, Chair, Lublin University of Technology (Poland)

Zdzisław Jankiewicz, Vice Chair, Institute of Electronic Materials, Warsaw (Poland) and Military University of Technology, Warsaw (Poland)

Paweł Mergo, Secretary, Maria Curie-Skłodowska University, Lublin (Poland)

Krzysztof Abramski, Wrocław University of Technology (Poland)

Elżbieta Bereś-Pawlik, Wrocław University of Technology (Poland)

Wojtek J. Bock, Photonics Research Center, Université du Québec en Outaouais (Canada)

Anna Cysewska-Sobusiak, Poznań University of Technology (Poland) Andrzej W. Domański, Warsaw University of Technology (Poland) Jan Dorosz, Białystok University of Technology (Poland) Vladimir Firago, Belarussian State University, Minsk (Belarus) Wojciech Gawlik, Jagiellonian University, Kraków (Poland)

Krzysztof Holejko, deceased, Warsaw University of Technology (Poland)

Zenon Hotra, Lviv Polytechnic National University (Ukraine)

Leszek R. Jaroszewicz, Military University of Technology, Warsaw (Poland)

Bohdan Kosmowski, Gdańsk University of Technology (Poland)

Andrzej Kotyra, Lublin University of Technology (Poland)

Andrzej Kowalski, Warsaw University of Technology (Poland)

Małgorzata Kujawińska, Warsaw University of Technology (Poland)

Zygmunt Kuczyński, Institute of Electronic Materials Technology, Warsaw (Poland)

Tomasz Nasiłowski, Military University of Technology, Warsaw (Poland) Sergiusz Patela, Wrocław University of Technology (Poland) Sergei Pavlov, Vinnitsia National Technical University, Lviv (Ukraine) Tadeusz Pustelny, Silesian University of Technology, Gliwice (Poland) 
Marek Ratuszek, deceased, University of Technology and Life Science, Bydgoszcz (Poland)

Ryszard S. Romaniuk, Warsaw University of Technology (Poland) Bohdan Stadnyk, Lviv Polytechnic National University (Ukraine) Paweł Szczepański, Warsaw University of Technology (Poland)

Mieczysław Szustakowski, Military University of Technology, Warsaw (Poland)

Hugo Thienpont, Free University of Brussels (Belgium)

Wacław Urbańczyk, Wrocław University of Technology (Poland)

Jan Wasylak, AGH University of Science and Technology, Kraków (Poland)

\section{Organizing Committee}

Wiesław Podkościelny, Chair, University of Maria Curie -Skłodowska, Lublin (Poland)

Paweł Komada, Vice Chair, Lublin University of Technology (Poland)

Andrzej Kotyra, Lublin University of Technology (Poland)

Piotr Kisała, Lublin University of Technology (Poland)

Lidia Czyżewska, University of Maria Curie-Skłodowska, Lublin (Poland)

Jacek Klimek, University of Maria Curie-Skłodowska, Lublin (Poland)

\section{Session Chairs}

Opening Plenary Session on Hot Topics in Optical Fiber Technology Waldemar Wójcik, Lublin University of Technology (Poland)

Wieslaw L. Woliński, Warsaw University of Technology (Poland)

Wojtek J. Bock, Photonics Research Center, Université du Québec en Outaouais (Canada)

Optical Fibers and Planar Optical Waveguides

Ryszard S. Romaniuk, Warsaw University of Technology (Poland)

Biophotonics

Waldemar Wójcik, Lublin University of Technology (Poland)

Graphen and New Materials in Optical Fiber Technology

Tadeusz Pustelny, Silesian University of Technology, Gliwice (Poland)

Microstructural and Photonic Optical Fibers

Tomasz R. Woliński, Warsaw University of Technology (Poland)

Optical Fiber Sensors

Ryszard S. Romaniuk, Warsaw University of Technology (Poland) 
Nonlinear and Active Optical Fibers

Ela Bereś-Pawlik, Wrocław University of Technology (Poland)

Active Glasses for Optical Fibers

Wacław Urbańczyk, Wrocław University of Technology (Poland)

Photonics Applications

Andrzej Kotyra, Lublin University of Technology (Poland)

Optoelectronic Systems and Associated Technologies

Zdzisław Jankiewicz, Institute of Electronic Materials, Warsaw (Poland) and Military University of Technology, Warsaw (Poland)

Poster Session on Optical Fiber Technology

Wiesław L. Woliński, Warsaw University of Technology (Poland)

Zdzisław Jankiewicz, Institute of Electronic Materials, Warsaw (Poland) and Military University of Technology, Warsaw (Poland)

Teaching of Photonics at Universities

Tomasz R. Wolinski, Warsaw University of Technology (Poland)

Workshop on Optical Fiber Technology

Paweł Mergo, University of Maria Curie-Skłodowska, Lublin (Poland) 
Proc. of SPIE Vol. 8698 869801-10

Downloaded From: https://www.spiedigitallibrary.org/conference-proceedings-of-spie on 26 Apr 2023 Terms of Use: https://www.spiedigitallibrary.org/terms-of-use 


\section{Introduction}

The Symposium on Optical Fibers and Their Application is a kind of a forum of national science in this branch of Photonics. The Symposium usually hosts many guests from this geographical region, especially from Ukraine and Belarus. It is organized every year and a half by two major optical fiber technology and application centers located in Białystok at Białystok University of Technology and in Lublin at Maria Curie-Skłodowska University and Technical University of Lublin. The conference belongs to a bigger circle of national conferences on optoelectronics, optics, photonics, sensors, and laser technology which are under a general patronage of professional community organizations like the Polish Ceramic Society, Photonics Society of Poland, Polish Optoelectronics Committee of the Association of Polish Electrical Engineers, and Section of Optoelectronics in the Committee of Electronics and Telecommunications, and the Polish Academy of Sciences.

The XIV Conference on Optical Fibers and Their Applications was held the 9-12 October 2012. The Conference was opened at the Energetyk Resort in Nałęczów, near Lublin, and the accompanying School/Workshop on Optical Fiber Technology was held in Lublin at UMCS OFT Laboratory. The conference series has been organized since 1976, from the beginning in the Jabłonna Village Palace near Warsaw, and then in a two year cycle conversely in Białowieża by the Białystok University of Technology (Prof. Jan Dorosz, with emphasis on applications, especially non-telecom ones) and in Krasnobród - now in Nałęczów by UMCS Lublin (the late Dr Jan Wójcik, Prof. J. Rayss, now Dr. W. Podkościelny and Dr P. Mergo) and Lublin University of Technology (Prof. W. Wójcik, with emphasis on technology and telecom applications). The first conference in Białowieża, held in 1982, focused on non-telecommunication application of optical fibers. During this period the conferences in Lublin and then Krasnobród now in Nałęczów were more focused on technology and metrology of optical fibers supplementing the application and construction topics moved in Białowieża. The conference series on Optical Fibers and Their Applications has been organized in this country for more than 30 years. It was initiated by the late professors: J. Groszkowski, A. Smoliński, A. Waksmundzki, M. Pluta, B. Paszkowski, and Z. Szpigler. These conferences mostly gather the whole country's researchers and optical fiber and optoelectronics experts as well as a large number of students and international guests.

The XIV Conference was opened by Prof W. Wójcik at the Pro-Rector of Lublin University of Technology and Dean of the Faculty of Chemistry of UMCS. The national expertise in optical fibers was gathered during the recent years around several big organizations, some of them with international roots: Section of Optoelectronics, Committee of Electronics and Telecommunications, Polish Academy of Sciences; Polish Committee of Optoelectronics, Association of Polish 
Electrical Engineers; the Polish Chapter of SPIE. The latter organization registered in this country as a Society was transformed in 2008 to the Photonics Society of Poland. These organizations cooperate with SPIE, IEEE Poland Section and Photonics Chapter, Section of Optics by Polish Physical Society and Polish Ceramic Society.

During the conference opening ceremony Prof. W. Wójcik reminisced about the past contributors and participants of the Lublin - Krasnobród (now Nałęczów) Conferences. The national experts of guided wave, laser, and semiconductor optoelectronics meeting in Krasnobród, Nałęczów, Białowieża and Świnoujście (Laser Technology Symposia) managed to integrate their activities in the frame of many optoelectronics research programs carried out during these years. These were programs were realized with partners national, central, departmental, priority, university and recently from Europe. Continuing work on these projects lead to numerous scientific and technical achievements as well, and were a major factor in building many photonic firms in this country and modernizing the teaching at technical universities.

The Nałęczów Conference gathered around 100 participants. Over 60 papers in oral and poster sessions were presented. Most papers originated from university centers active in optoelectronics such as: Silesian University of Technology in Gliwice, Białystok, Warsaw and Lublin as well as UMCS in Lublin. The topical coverage of the meeting was materials for optoelectronics: in particular materials for optical fiber technology, fabrication of optical fibers, components and subassemblies for optoelectronics, metrology of optical fibers, metrology of optoelectronic components and devices, applications of optical fibers, and education in optoelectronics and photonics. A few plenary papers presented touched on very current and hot problems in optoelectronics.

The technological sessions of the Symposium presented the works from three main national centers where optical fibers are pulled. These are Faculty of Chemistry, University of Maria Curie Skłodowska in Lublin, Faculty of Electrical Engineering at Białystok University of Technology and Institute of Electronic Materials Technology in Warsaw. A number of research centers in this country and internationally use these optical fibers for optical fiber sensors and photonic instrumentation devices. A large group of applications concerned microstructural photonic optical fibers filled or impregnated with liquid crystals, which are highly nonlinear optical substances, much more nonlinear than glasses. This group of papers originated from the laboratories at Warsaw and Wrocław Universities of Technology, but the fibers were manufactured at UMCS in Lublin and at ITME in Warsaw.

The Symposium organizers have provided very favorable participation conditions for Ph.D. and M.Sc. students; who were significant participators in the symposium. The majority of the papers were presented by young researchers, which supports the belief that this branch of technology is vivid and promises future development. The Editors would like to thank Dr. Andrzej Smolarz from Lublin 
University of Technology for his devoted help as a Technical Editor of this volume of Proceedings from the XIV Conference on Optical Fibers and Their Applications, Nałęczów 2012.

\section{References}

1. W.L.Woliński, Z.Jankiewicz, R.S.Romaniuk, Laser Technology 2012: Progress in Lasers, Proc. SPIE 8703

2. W.L.Woliński, Z.Jankiewicz, R.S.Romaniuk, Laser Technology 2012: Application of in Lasers, Proc. SPIE 8704

3. R.S.Romaniuk, Photonics Applications in Astronomy, Communications, Industry, and High-Energy Physics Experiments 2012, Proc. SPIE 8454

4. J.Dorosz, R.S.Romaniuk (Editors) ,Optical Fibers and Their Applications 2011, Proc. SPIE 8010

5. J.Dorosz, R.S.Romaniuk, T.R.Woliński (Editors), Optical Fibers and Their Applications 2008, Proc. SPIE 7120

6. J.Dorosz, R.S.Romaniuk (Editors), Optical Fibers and Their Applications 2003, Proc. SPIE 5028

7. J.Dorosz, R.S.Romaniuk (Editors), Optical Fibers and Their Applications 1999, Proc. SPIE 3731

8. M.Szustakowski, R.S.Romaniuk, Optical Fibers and Their Applications 1989, Proc. SPIE 1085

9. M.Szustakowski, R.S.Romaniuk, Optical Fibers and Their Applications 1986, Proc. SPIE 0670

10. W.Wójcik, R.S.Romaniuk, Optical Fibers and Applications, International Journal of Electronics and Telecommunications, vol.59, no.1, in press (2013)

\section{Ryszard S. Romaniuk Waldemar Wójcik}


Proc. of SPIE Vol. 8698 869801-14

Downloaded From: https://www.spiedigitallibrary.org/conference-proceedings-of-spie on 26 Apr 2023 Terms of Use: https://www.spiedigitallibrary.org/terms-of-use 